\title{
Antimicrofouling activities of marine macroalga Dictyota dichotoma from the Red Sea
}

Alaa Aref Abdullah Gadhi, Mohsen M. O. El-Sherbiny, Abdul Mohsin A. Al-Sofyani, Mohammad Abdulaziz Ba-Akdah, "Sathianeson Satheesh

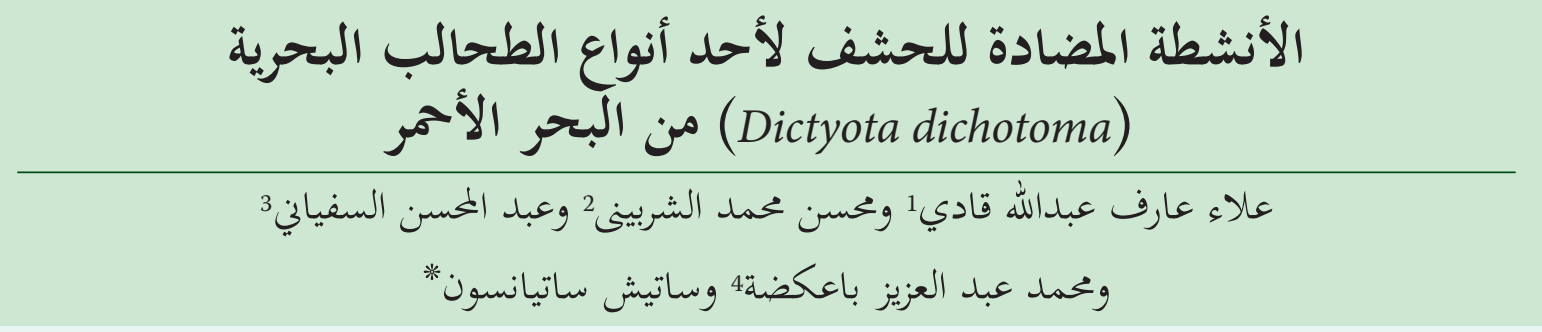

ABSTRACT. Marine organisms produce a variety of secondary metabolites mainly for achieving the defence against the competitors and predators. These compounds could be used as natural product antifoulants for the management of biofouling growth on marine structures. To understand the antifouling defence strategies of marine macroalgae, the macroalga Dictyota dichotoma was collected from the Obhur Creek of Red Sea, Saudi Arabia and extracted using methanol. Surface and total extraction methods were performed and tested against a bacterial strain isolated from the microfouling assemblages. The extracts obtained from the macroalgal samples have strong antibacterial and antibiofilm activities against the bacterial strain isolated from the marine microfouling assemblages. The percentage of growth varied significantly between the bacterial culture treated with extracts and control. The total extracts showed strong bacterial growth inhibitory activities in culture plate method. In microtitre plate assay, surface extract showed higher biofilm inhibitory activity than total extract. GC-MS analysis indicated considerable variations in the metabolic profile of the surface and total extracts with higher number of compounds in the surface extract. This study revealed the importance of surface-associated compounds in antifouling defence mechanism of the marine macroalgae.

KEYwORDS: Seaweeds; biofouling; antifouling; bioactive compounds; biofilms; chemical defence; Red Sea

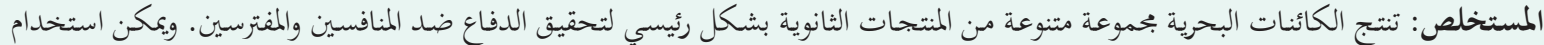

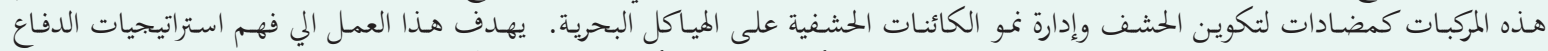

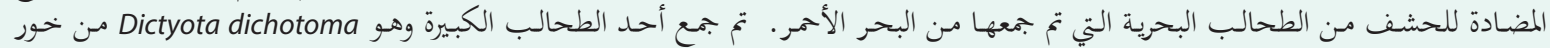

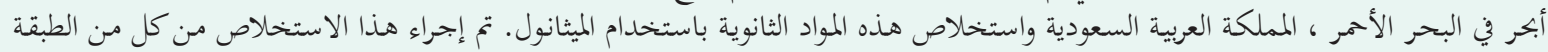

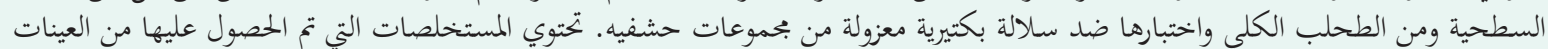

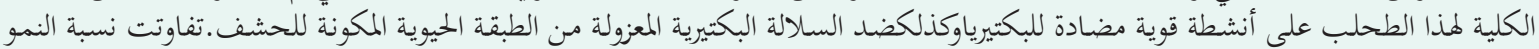

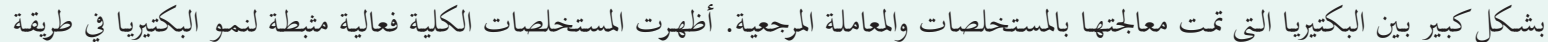

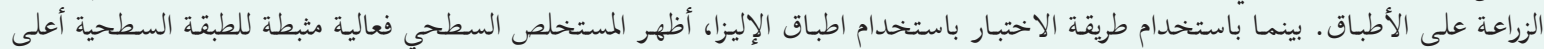

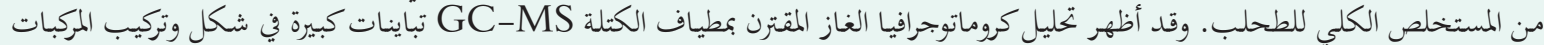

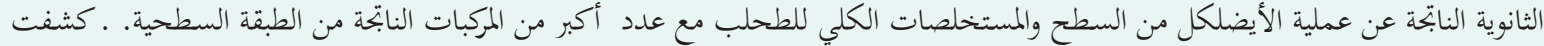

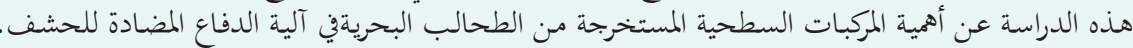

$$
\begin{aligned}
& \text { الكلمات المفتاحية: الكلمات الدالة:الطحالب البحرية، المضادة للحشف، مركبات نشطة، الدفاع الكيميائي، البحر الاحمر }
\end{aligned}
$$

\section{Introduction}

I $\mathrm{n}$ the marine environment, biofilm development on hard surfaces is the initial process, which subsequently will lead to the attachment of marine organisms, a process commonly known as biofouling growth on substrates (Satheesh et al. 2016). The attachment of bacterial communities will help the settlement of higher organisms on the surfaces (Hadfield and Paul 2001; Huang et al. 2012). Biofouling, involve all settling organisms such as microfoulers (bacteria, fungi, protozoans, microalgae) and macrofoulers such as barnacles, tube

"Sathianeson Satheesh $(\)$ ssathianeson@kau.edu.sa. Department of Marine Biology, Faculty of Marine Sciences, King Abdulaziz University, Jeddah, Saudi Arabia worms, mussels, and bryozoans (Stoodley et al. 2002; Satheesh and Wesley 2008). Generally, biofouling is a main concern for underwater man-made structures and a costly problem for marine technology sectors which needs frequent cleaning and antifouling measures (Armstrong et al. 2000; Qian et al. 2009; Satheesh et al. 2016). For example, biofilm formation and subsequent biofouling may increase $14 \%$ of the fuel cost in ships and $8 \%-29 \%$ loss in propulsive power has also been attributed to due to mature marine biofilms (Schultz et al. 2004; Salta et al. 2013)

Due to the economic loss, various antibiofilm and antifouling strategies are currently practiced in the marine technology sector (Satheesh et al. 2016; Dahms and Dobretsov 2017). The most common antifoulants are 
Table 1. Compounds identified from the total extract of $D$. dichotoma based on the peaks observed in the GC-MS spectrum

\begin{tabular}{|c|c|c|c|}
\hline Sl. No & $\begin{array}{l}\text { Retention } \\
\text { Index }\end{array}$ & Compound name & $\begin{array}{l}\text { Molecular weight } \\
\left(\mathrm{g} \mathrm{mol}^{-}{ }^{-}\right)\end{array}$ \\
\hline 1 & 1937 & Ethyl pentyl phthalate & 264 \\
\hline 2 & 2573 & 4-Methoxy-3-[(2,4,6-trichlorophenoxy)methyl] benzaldehyde & 344 \\
\hline 3 & 659 & 2-Butynol & 70 \\
\hline 4 & 2434 & Dihexyl phthalate & 334 \\
\hline 5 & 2235 & Phthalic acid, butyl hexyl ester & 306 \\
\hline 6 & 2633 & 1,2-Benzenedicarboxylic acid, butyl decyl ester & 362 \\
\hline 7 & 2832 & Phthalic acid, butyl dodecyl ester & 390 \\
\hline 8 & 2171 & Pthalic acid butyl ioshexyl ester & 306 \\
\hline 9 & 3589 & Propanoic acid, 3,3'-thiobis-didodecyl ester & 514 \\
\hline 10 & 3986 & Propanoic acid, 3,3'-thiobis-ditetradecyl ester & 570 \\
\hline 11 & 2011 & Octadecyl trifluroacetate & 366 \\
\hline 12 & 1710 & Undecane, 3-cyclohexyl & 238 \\
\hline 13 & 4085 & Hexadecane,1,1-bis (dodecyloxy) & 594 \\
\hline
\end{tabular}

mainly based on heavy metals (copper, zinc) or tributyltin (TBT) and applications of these compounds creates many harmful problems to the environment (Bellas 2006; Thomas and Brooks 2010). These chemical coatings are not only toxic to fouling organisms but also toxic to other non-target organisms (Fingerman 1998; Hoch 2001). TBT is considered as one of the most toxic materials discharged into the marine environment due to antifouling applications (Evans et al. 1995). International Maritime Organization (IMO) banned the use of TBT coatings because of the toxic effects to marine organisms and environment (Satheesh et al. 2016).

Among marine organisms, macroalgae attracted much attention for the natural product research (de Nys et al. 1995; Sudatti et al. 2008). This was evidenced by

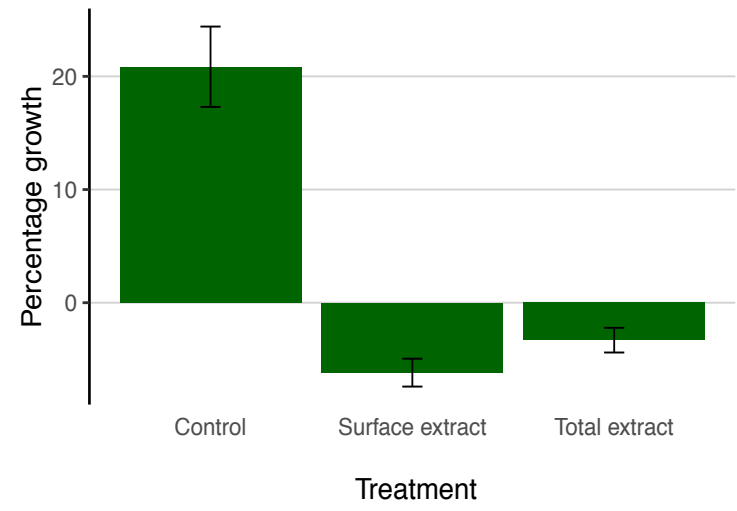

Figure 1. Percentage of bacterial growth by $D$. dichotoma extracts. Bacterial growth was measured using spectrophotometric method for $5 \mathrm{~h}$. A negative percentage indicates inhibition of bacterial growth in compariton to the control. Control growth is that observed without extract treatment. Error bars indicate the standard deviation of the mean $(\mathrm{n}=3)$. the large number of publications available in the scientific domain (see reviews: Perez et al. 2016; Dahms and Dobretsov 2017). Marine macroalgae are particularly exposed to many epiphytes (those organisms settling on it) in the environment. To avoid the settlement of organisms on their surfaces, the macroalgae are reported to produce chemically active metabolites (Plouguerné et al. 2008). These compounds are of interest due to many drug leads that are isolated from the macroalgae. Some studies have analysed the effects of macroalgal secondary metabolites on the planktonic bacterial community (Nylund and Pavia 2005; Paul et al. 2006; Dubber and Harder 2008; Lam et al. 2008). Lu et al. (2008) observed that macroalgae such as Ulva clathrata have an inhibitory effect on Vibrio anguillarum, a fish and mussel pathogen.

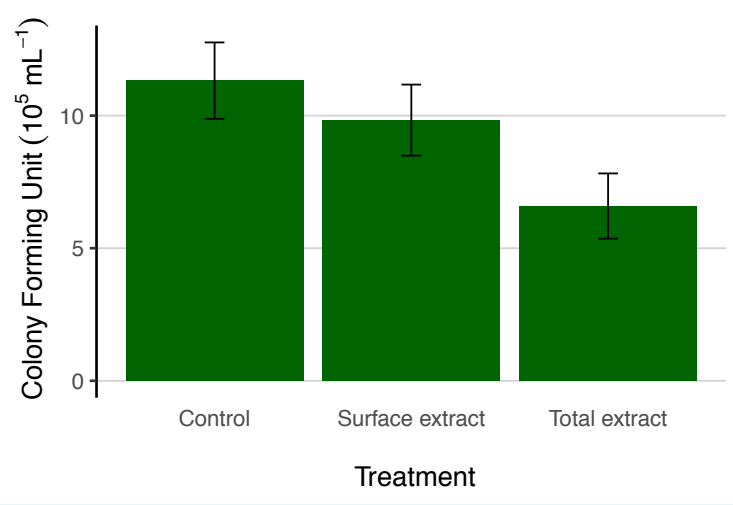

Figure 2. Numbers of colony forming units (CFUs) in the presence and absence of extracts (total and surface) of $D$. dichotoma. Growth inhibitory activity was studied by traditional culture plate method. Error bars indicate the standard deviation of the mean $(n=3)$. Control=without extract treatment. 
Table 2. Compounds identified from the surface extract of $D$. dichotoma by GC-MS analysis (continued on next page)

\begin{tabular}{|c|c|c|c|}
\hline Sl. No & $\begin{array}{l}\text { Retention } \\
\text { Index }\end{array}$ & Compound name & $\begin{array}{l}\text { Molecular weight } \\
\left(\text { g mol-1 }^{1}\right)\end{array}$ \\
\hline 1 & 1117 & Azetidin-2-one 3,3-dimethyl-4-(1-aminoethyl)- & 142 \\
\hline 2 & 1517 & 2-Formyl histamine & 139 \\
\hline 3 & 1744 & Benzene ethanamine, 2,5-difluoro- beta.,3,4-trihydroxy- $\mathrm{N}$-methyl- & 219 \\
\hline 4 & 931 & Octodrine & 129 \\
\hline 5 & 1081 & 1-(5-Bicyclo[2.2.1] heptyl) ethylamine & 139 \\
\hline 6 & 1662 & Benzene propanoic acid, .alpha.-(1-aminoethyl)-, $\left[\mathbf{R}-\left(\mathbf{R}^{*}, \mathbf{R}^{*}\right)\right]-$ & 193 \\
\hline 7 & 2135 & Propanamide, 3-(3,4-dimethylphenylsulfonyl)- & 241 \\
\hline 8 & 1171 & Benzene ethanamine, .alpha.-methyl- & 135 \\
\hline 9 & 1716 & Benzene methanol, 2-(2-aminopropoxy)-3-methyl- & 195 \\
\hline 10 & 907 & p-Xylene & 106 \\
\hline 11 & 907 & O-Xylene & 106 \\
\hline 12 & 2220 & 4-Oxatricyclo $[4.2 .1 .0(3,7)]$ nonane-9-carboxamide, 5-oxo- $\mathrm{N}$-(phenyl-methyl)- & 271 \\
\hline 13 & 1190 & Benzene ethanol, .alpha.,.beta.-dimethyl- & 150 \\
\hline 14 & 824 & 1,3-Cyclopentadiene, 5-(1-methylethylidene)- & 106 \\
\hline 15 & 1369 & 3-Pyridine carboxaldehyde, $\mathrm{O}$-acetyloxime, $(\mathrm{E})$ - & 164 \\
\hline 16 & 1500 & Piperidine, 3-phenyl- & 161 \\
\hline 17 & 1307 & Cathinone & 149 \\
\hline 18 & 2135 & Propanamide, 3-(3,4-dimethylphenylsulfonyl)- & 241 \\
\hline 19 & 1913 & N-Methyl-N-(toluene-4-sulfonylmethyl)-acetamide & 241 \\
\hline 20 & 1334 & Phenyl propanolamine & 151 \\
\hline 21 & 806 & Methylpent-4-enylamine & 99 \\
\hline 22 & 1294 & 1-Methyl decylamine & 171 \\
\hline 23 & 2190 & Cystine & 240 \\
\hline 24 & 1787 & dl-Alanyl-dl-norleucine & 202 \\
\hline 25 & 1891 & Nitro-L-arginine & 219 \\
\hline 26 & 1451 & N(Epsilon)-methyl-1-lysine & 160 \\
\hline
\end{tabular}

In this study, the macroalga Dictyota dichotoma collected from the Jeddah coastal waters of Red Sea was screened for antimicrobial and antibiofilm activities against bacterial strain isolated from marine biofilms. The main objective of this study was to analyse the role of surface-associated molecules in achieving the chemical defence of macroalgae against the microfouling organisms. Result obtained in this study will improve our knowledge of the chemical defence strategies of macroalgae and lead to the isolation of novel metabolites from the Red Sea macroalgae that can be used as natural product antifoulants.

\section{Materials and Methods}

The macroalga Dictyota dichotoma (Hudson) J.V. Lamouroux (Class: Phaeophyceae) was collected from the Obhur Creek on the Jeddah coast (near King Abdulaziz
University Marine Station, Obhur) and transported to the laboratory. In the laboratory, macroalgal samples were rinsed with filtered (Millipore, $0.47 \mu \mathrm{m}$ ) seawater to remove the debris and other attached organisms and used for extraction. Total extraction and surface extraction were followed in order to extract as much as active compounds from the algal samples. Methanol was the solvent used for both types of extraction. About $10 \mathrm{~g}$ fresh algal samples were used for both surface and total extraction. In total extraction, the fresh macroalgal samples were extracted using methanol $(5 \mathrm{ml})$ after grinding the wet samples using pestle and mortar. The macerated samples were kept in methanol for $5 \mathrm{~h}$ at room temperature in dark and after that centrifuged at $3000 \mathrm{rpm}$ to remove the solid part. The solvent part was collected and maintained at $-20^{\circ} \mathrm{C}$ until further analysis. The surface molecules were extracted by dipping the algal samples in methanol $(5 \mathrm{~mL})$ for 10 seconds. After that, the extract 
Table 2 (continued). Compounds identified from the surface extract of $D$. dichotoma by GC-MS analysis

\begin{tabular}{|c|c|c|c|}
\hline Sl. No & $\begin{array}{l}\text { Retention } \\
\text { Index }\end{array}$ & Compound name & $\begin{array}{l}\text { Molecular weight } \\
\left(\mathrm{g} \mathrm{mol}^{-1}\right)^{-}\end{array}$ \\
\hline 27 & 1904 & 5-(Prop-2-enoyloxy) pentadecane & 282 \\
\hline 28 & 1693 & Imidazole, 2-amino-5-[(2-carboxy) vinyl]- & 153 \\
\hline 29 & 1673 & Pentafluoropropionic acid, pentadecyl ester & 374 \\
\hline 30 & 1613 & Tetradecyl trifluoroacetate & 310 \\
\hline 31 & 1773 & Pentafluoropropionic acid, hexadecyl ester & 388 \\
\hline 32 & 1435 & Heptafluorobutyric acid,n-tridecyl ester & 396 \\
\hline 33 & 1669 & 4-Heptafluorobutyryloxy hexadecane & 438 \\
\hline 34 & 1440 & Dimethyl phthalate & 194 \\
\hline 35 & 1508 & Benzoic acid, 2-(1-oxopropyl)-, methyl ester & 192 \\
\hline 36 & 1555 & Phenol, 2,6-bis(1,1-dimethylethyl)- & 206 \\
\hline 37 & 2255 & Pentanoic acid, 5-hydroxy-, 2,4-di-t-butylphenyl esters & 306 \\
\hline 38 & 1484 & 1-(3,6,6-Trimethyl-1,6,7,7a-tetrahydrocyclopenta[c]pyran-1-yl)ethanone & 206 \\
\hline 39 & 1555 & Phenol, 3,5-bis(1,1-dimethylethyl)- & 206 \\
\hline 40 & 1549 & 3-Trifluoroacetoxytetradecane & 310 \\
\hline 41 & 1639 & Diethyl Phthalate & 222 \\
\hline 42 & 1729 & Phthalic acid, allyl ethyl ester & 234 \\
\hline 43 & 1937 & Phthalic acid, ethyl pentyl ester & 264 \\
\hline 44 & 2235 & Phthalic acid, butyl hexyl ester & 306 \\
\hline 45 & 2434 & 1,2-Benzenedicarboxylic acid, butyl octyl ester & 334 \\
\hline 46 & 2037 & Dibutyl phthalate & 278 \\
\hline 47 & 1973 & 1,2-Benzenedicarboxylic acid, butyl 2-methylpropyl ester & 278 \\
\hline 48 & 1341 & Hexasiloxane, 1,1,3,3,5,5,7,7,9,9,11,11-dodecamethyl- & 430 \\
\hline 49 & 1580 & Benzoic acid, 3-methyl-2-trimethylsilyloxy-, trimethylsilyl ester & 296 \\
\hline 50 & 1710 & Octasiloxane, 1,1,3,3,5,5,7,7,9,9,11,11,13,13,15,15-hexadecamethyl- & 578 \\
\hline 51 & 1526 & Heptasiloxane, 1,1,3,3,5,5,7,7,9,9,11,11,13,13-tetradecamethyl- & 504 \\
\hline 52 & 1339 & Silane, trimethyl[5-methyl-2-(1-methylethyl)phenoxy]- & 222 \\
\hline
\end{tabular}

was centrifuged and maintained at $-20^{\circ} \mathrm{C}$ for antibiofilm assays.

\section{Bacterial growth inhibition assay (Spectropho- tometer assay)}

The bacterial strain Vibrio harveyi (NCBI GenBank accession number: KY266820) isolated from the marine biofilm developed on nylon nets submerged in the Jeddah coastal waters of the Red Sea (Balqadi et al. 2017) was used as a target bacteria for antibiofilm assays. Before starting the antibiofilm assays, the bacterial strain was inoculated into marine nutrient broth (Zobell marine broth, HiMedia, India). The broth was kept at $28^{\circ} \mathrm{C}$ in an incubator for $48 \mathrm{~h}$ and after the incubation, the optical density (OD) of the culture was adjusted to 1 at $530 \mathrm{~nm}$ (Sayem et al. 2011) to maintain equal bacterial cells. Three millilitres of bacterial culture was taken in test tubes and $50 \mu \mathrm{L}$ macroalgal extract (both surface and whole tissue extracts) was added and the control tubes were maintained without any extracts. Methanol control was also maintained and no growth inhibition activity was observed. The optical density of the bacterial culture was measured at $670 \mathrm{~nm}$ (modified from Pan et al. 2014) in a spectrophotometer for a period of $5 \mathrm{~h}$ (OD was measured at one-hour intervals for $5 \mathrm{~h}$ duration). The experiment was carried out in replicate $(n=3)$ and the mean \pm standard deviation values were considered. The percentage of bacterial growth/inhibition was calculated using the following formula (Viju et al. 2016).

$$
G R(\%)=\frac{O D_{\text {final }}}{O D_{\text {initial }}} 100
$$

Eq.(1)

where GR is the growth rate and OD is optical density at the beginning $\left(O D_{\text {initial }}\right)$ and at the end of the experiment 


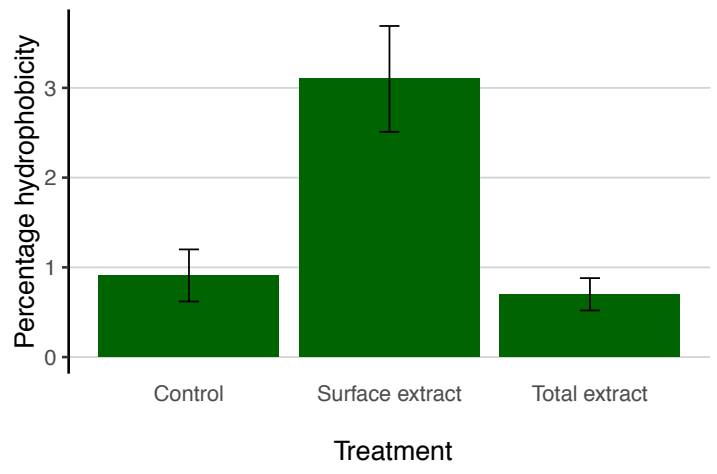

Figure 3. Effect of $D$. dichotoma extracts (total and surface extracts) on hydrophobicity of biofilm forming bacterial cells. Control=without extract treatment. Error bars indicate the standard deviation of the mean $(\mathrm{n}=3)$.

$$
\left(O D_{\text {final }}\right) \text {. }
$$

\section{Bacterial growth inhibition assay (Culture plate method)}

The bacterial culture $\left(\mathrm{OD}_{530}=1\right)$ was also used to study the growth inhibition activities of macroalgal extracts by culture plate method. The bacterial culture $(3 \mathrm{~mL})$ was taken in a test tube and $50 \mu \mathrm{L}$ algal extract was added. Bacterial culture without macroalgal extract treatment was considered as a control. The test tubes with bacterial cultures treated with macroalgal extracts and controls (in replicates, $\mathrm{n}=3$ ) were then incubated for $24 \mathrm{~h}$ at $28^{\circ} \mathrm{C}$. After $24 \mathrm{~h}, 100 \mu \mathrm{L}$ of bacterial culture from the test tube was spread on marine agar plates and the culture plates were incubated at $28^{\circ} \mathrm{C}$ in an incubator for $24-48 \mathrm{~h}$. The bacterial colonies developed in each plate was counted and mean ( \pm standard deviation) colony counts were expressed as colony forming units, $\mathrm{CFU}, \mathrm{mL}^{-1}$.

\section{Effects of macroalgal extracts on cell surface hydrophobicity of bacteria}

The bacterial cell surface hydrophobicity was measured according to the MATH (Microbial Adhesion to Hydrocarbons) assay described by Rosenberg et al. (1980).

About $3 \mathrm{~mL}$ of bacterial culture was taken in test tubes and $50 \mu \mathrm{L}$ of macroalgal extract was added. After $1 \mathrm{~h}$ the OD of the culture was measured at $530 \mathrm{~nm}$ in a spectrophotometer. To this culture, $300 \mu \mathrm{L}$ of hexane was added and vortexed for $1 \mathrm{~min}$. The culture was then left for $10 \mathrm{~min}$. to allow the separation of two phases. The aqueous phase of the culture was separated and used for OD measurement as above. The percentage of hydrophobicity ( $\mathrm{HB}(\%)$ was calculated using the following formula.

$$
H B(\%)=\left(1-A / A_{0}\right) 100
$$

Where $\mathrm{HB}(\%)$ is the percentage hydrophobicity as measured by bacterial cell adherence to hexane and $A$ is the Optical Density at $530 \mathrm{~nm}$, before $\left(\mathrm{A}_{0}\right)$ and after $(\mathrm{A})$

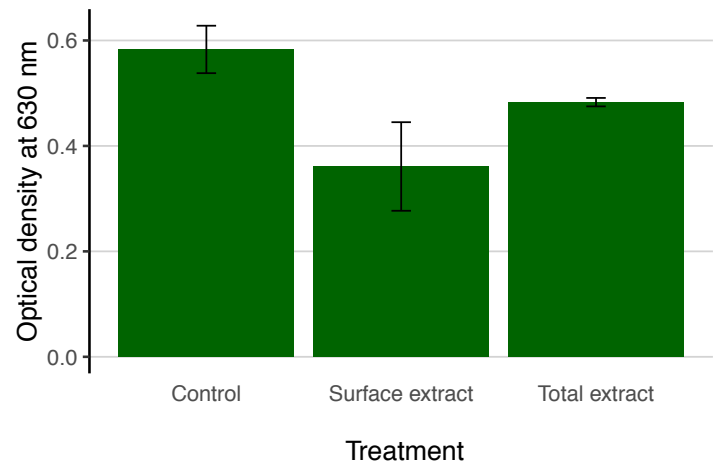

Figure 4. Antibiofilm activity of $D$. dichotoma extracts (total and surface extracts) against Vibrio harveyi. Error bars indicate the standard deviation of the mean $(n=3)$.

washing the cell suspension with hexane.

\section{Biofilm growth inhibition activity of macroal- gal extracts - microtiter plate assay}

The anti-settlement activity of macroalgal extracts against the bacteria was determined by the 96-well microtiter plate method described by Coffey and Anderson (2014). The bacterial culture (OD adjusted to the OD 1.0 at $530 \mathrm{~nm}$ ) was used for the antibiofilm assay. The wells of the microtitre plate were filled with $100 \mu \mathrm{L}$ of bacterial culture and $5 \mu \mathrm{L}$ of the extracts were added. The controls were maintained without adding any extract. The plates were incubated at $28^{\circ} \mathrm{C}$ for $24 \mathrm{~h}$. After incubation, the plate was inverted to remove the unattached bacterial cells and rinsed with sterile water. After that, $150 \mu \mathrm{L}$ of $0.1 \%$ crystal violet was added to each well of the microtiter plate. The plates were kept for $10 \mathrm{~min}$. for staining of the cells and after $10 \mathrm{~min}$. the plate was inverted to remove crystal violet stain. The wells were rinsed again with sterile water to remove the excess stain. Finally, glacial acetic acid $(150 \mu \mathrm{L})$ was added to each well and kept for $10 \mathrm{~min}$. After $10 \mathrm{~min}$., the plates were read at $630 \mathrm{~nm}$ in a Biotek plate reader (Winooski, USA).

\section{Isolation and identification of the pathogen}

The bioactive compounds present in surface and total extracts of $D$. dichotoma was analysed by GC-MS (Shimadzu GC-MS QP 2010, Japan, Faculty of Meteorology, Environment and Arid land agriculture, King Abdulaziz University). The protocol described by El-Din and El-Ahwany (2016) for macroalgal extracts was used for the GC-MS analysis. The crude algal extracts were partially purified through silica gel column and analysed in a capillary silica column $(30 \mathrm{~m} \times 0.25 \mathrm{~mm} \times 0.25 \mu \mathrm{m})$ using helium as carrier gas ( $1.5 \mathrm{~mL}$ for $1 \mathrm{~min})$. The mass spectrometer was operated in the electron impact (El) mode at $70 \mathrm{eV}$ in the scan range of $40-700 \mathrm{~m} / \mathrm{z}$. The following MS conditions were used for getting the spectrum: split ratio: $1: 10$, injected volume: $1 \mu \mathrm{L}$, injector temperature: $250^{\circ} \mathrm{C}$, the oven temperature: initially $70^{\circ} \mathrm{C}$ for $3 \mathrm{~min}$ and 
then increased to $250^{\circ} \mathrm{C}$ at $14^{\circ} \mathrm{C} \mathrm{min}^{-1}$. The peaks observed in the GC-MS spectrum where compared with those available in NIST 11 - Mass Spectral Library for the identification of the compounds.

\section{Statistical analysis}

The data obtained from biofilm bacterial growth inhibition assay was analysed by one-way analysis of variance (ANOVA) followed by post hoc Tukey's test. Student's ' $t$ ' test was used to analyse the difference in biofilm inhibition activity of algal extracts and control. For all statistical tests $\mathrm{P}<0.05$ was considered as significant.

\section{Results}

\section{Bacterial growth inhibition assay- spectropho- tometric method.}

The biofilm bacterial culture treated with $D$. dichotoma extracts showed negative growth during the $5 \mathrm{~h}$ period. The biofilm bacterial culture without any treatment showed a growth of $20.82 \%$ during $5 \mathrm{~h}$ period under laboratory conditions (Fig 1). The total extract treated bacterial culture showed a negative growth of $-3.11 \%$ during the experiment period $(5 \mathrm{~h})$. The bacterial culture treated with the surface extract of the $D$. dichotoma also revealed negative growth $(-6.152 \%)$ compared to control. One-way ANOVA showed a significant variation in bacterial growth percentage between control and extract treated cultures $(\mathrm{F}=127 ; \mathrm{df}=2,8 ; \mathrm{P}<0.05)$. However, the bacterial growth inhibiting activity of total extract and surface extract did not differ significantly (Post hoc Tukey test: total extract vs surface extract, $\mathrm{p}=0.3$ ).

\section{Bacterial growth inhibition-culture plate meth- od}

In traditional culture plate method, the total extract exhibited strong growth inhibitory activity than the surface extract. The bacterial culture without any treatment showed 1,140,000 CFU, mL $\mathrm{m}^{-1}$ in culture plates (Fig. 2). About $665,000 \mathrm{CFU}, \mathrm{mL}^{-1}$ colonies were observed on the culture plates containing the bacteria treated with the total extract of $D$. dichotoma. In surface extract treatment, the number of colonies observed was comparatively higher than the total extract treatment $(988,000$ CFU, $\mathrm{mL}^{-1}$ ).

\section{Effects of macroalgal extracts on hydrophobic- ity of biofilm-forming bacterial cells}

The bacterial cell surface hydrophobicity of the biofilm-forming bacteria under normal conditions (control, without any algal extract treatment) was $0.9 \%$ (Fig. 3). However, when treated with algal extracts the bacterial cell hydrophobicity was either reduced or increased. The total extract of $D$. dichotoma reduced the bacterial cell surface hydrophobicity by $0.7 \%$. However, treatment with surface extract showed an increase in bacterial cell surface hydrophobicity (3.1\%).

\section{Quantification of biofilm prevention by mac- roalgal extracts: Microtitre plate assay}

The results of microtitre plate assay revealed that the macroalgal extracts inhibited the biofilm formation (Fig. 4). The inhibition of biofilm growth was evidenced by the low OD values observed from the cultures treated with the extracts. The bacterial cultures treated with total extract showed an OD value of 0.48 and for surface extract treatment the OD was observed as 0.36. Also, the OD values were significantly lower than the control (Student's- $t$ test: total extract, $\mathrm{t}=4.3, \mathrm{df}=2, \mathrm{p}=0.02$; surface extract $\mathrm{t}=-3.47, \mathrm{df}=2 ; \mathrm{p}=0.03$ ).

\section{GC-MS analysis of macroalgal extracts}

GC-MS analysis of macroalgal extracts revealed considerable differences between total and surface extracts (Fig 5). The total extract of $D$. dichotoma revealed 13 compounds in the GC-MS spectrum (Table 1). Most of the compounds are identified as phthalic acid derivatives. The compounds identified include ethyl pentyl phthalate, 4-methoxy-3-[(2,4,6-trichlorophenoxy) methyl] benzaldehyde, dihexyl phthalate, phthalic acid butyl dodecyl ester and phthalic acid butyl isohexyl ester. About 52 compounds (Table 2) were identified from the surface extract of $D$. dichotoma which include azetidine-2-one 3,3-dimethyl-4-(1-aminoethyl), 2-formyl histamine, benzene ethanamine, 2,5-difluoro- beta.,3,4-trihydroxy-N-methyl, -oxatricyclo [4.2.1.0(3,7)] nonane-9-carboxamide, 5-oxo- $\mathrm{N}$-(phenylmethyl), 1,3-cyclopentadiene, 5-(1-methylethylidene) and piperidine, 3-phenyl.

\section{Discussion}

Marine macroalgae are abundant in coastal ecosystems and play key roles in ecosystem functioning (Ba-akdah et al. 2016). As herbivory is high in marine ecosystems, the algae possess several defence systems against herbivores (Paul et al. 2001). Macroalgae also show antifouling defence by different ways such as the use of chemical and physical defences (Burns et al. 2003; da Gama et al. 2014) or symbiotic relationships between epibionts (e.g., bacteria) (Satheesh et al. 2016). Due to these chemical defence, macroalgae are one of the most important groups for natural product antifouling research (Nylund et al. 2007; Hellio et al. 2009; Viano et al. 2009; Saha and Wahl 2013; Othmani et al. 2016; Carvalho et al. 2017; Salama et al. 2017).

In the present study, surface and total extracts of the macroalgae $D$. dichotoma was tested against three important properties growth, cell surface hydrophobicity and biofilm formation (attachment) of the marine bacterial strain isolated from marine microfouling assemblages. The growth of the bacteria was inhibited by both surface and total extracts, though a higher percentage 

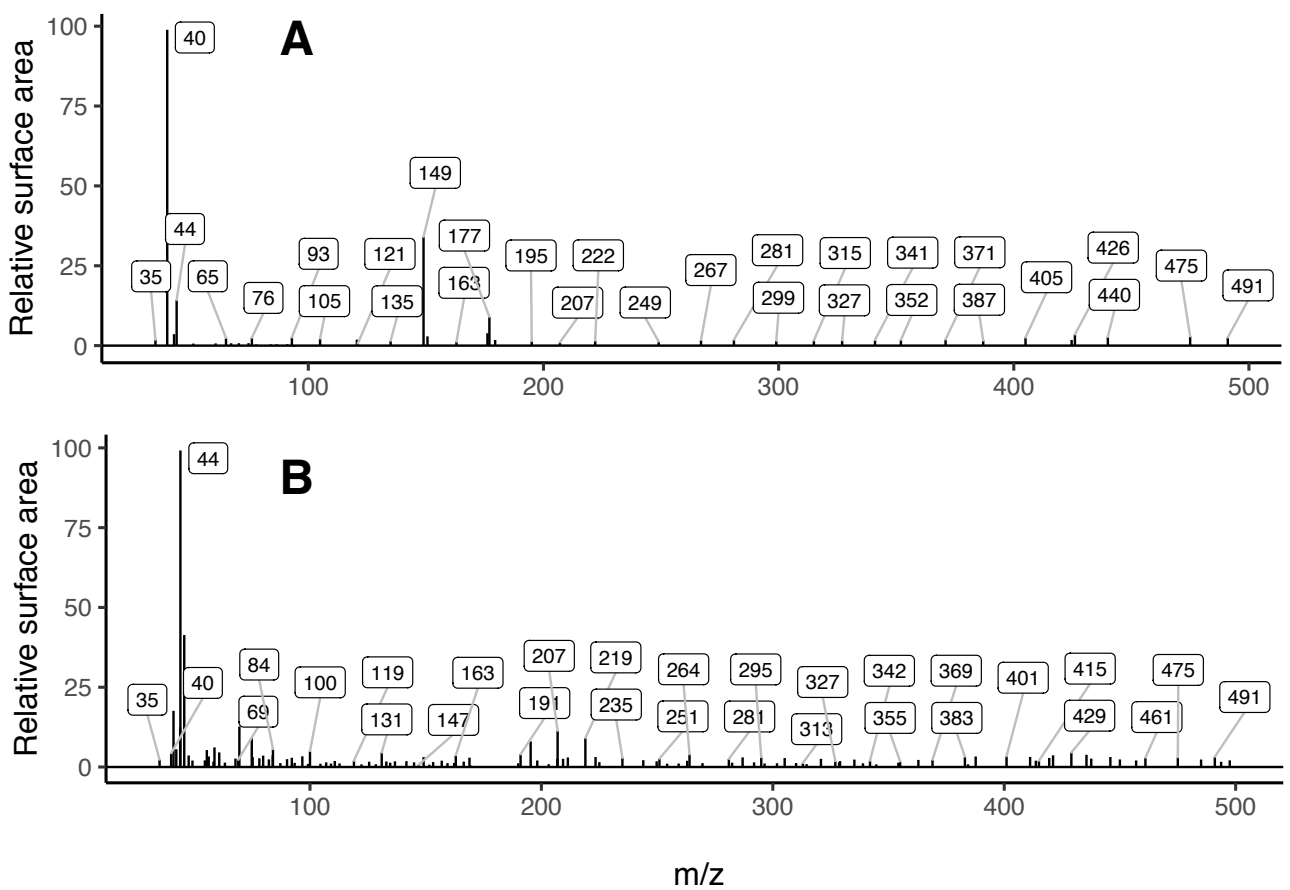

Figure 5. GC-MS analysis of D. dichotoma extracts. A). GC-MS spectrum obtained for total extract, B). GC-MS spectrum of surface extract.

of inhibition was observed in bacterial cultures treated with surface extracts (except in the culture plate method). Further, the extracts also possess antimicrobial activity that was evidenced by the negative growth percentages (indicating a decrease in bacterial counts from the beginning) observed in spectrophotometer assay. Antimicrobial activity of the genus Dictyota have been reported widely in the literature (Águila-Ramírez et al. 2012; Antonysamy et al. 2015).

The macroalgal extracts used in this study changed the bacterial cell hydrophobicity which is essential for attachment on surfaces. Bacterial cell surface hydrophobicity may play important role in biofilm formation on surfaces (Choi et al. 2013). This increase in cell surface hydrophobicity may be due to the release of outer membrane vesicles as an adaptive mechanism against the toxicity of extracts. Previous studies by Baumgarten et al. (2012) reported the release of membrane vesicles by the bacterium Pseudomonas putida strain DOT-T1E due to the toxicity of long-chain fatty alcohols, EDTA and heat. Generally, the if the hydrophobicity of the bacterial cell surface increases, then there will be a stronger attachment on hydrophobic surfaces and vice versa (Kochkodan et al. 2008; Giaouris et al. 2009; Krasowska et al. 2014). Hence, if the hydrophobicity is low then the bacteria prefer to settle on hydrophilic surfaces. In this study, the macroalgal extracts affected the normal hydrophobicity of the bacterial cells, but the attachment process may depend on other factors including surface characters and environmental conditions.

Chemical defence strategies of macroalgae and oth- er organisms in the marine ecosystems are the topics of research in recent years (da Gama et al. 2014; Lopanik 2014; Rhode et al. 2015; Sacristan-Soriano et al. 2017). The difference between the bioactivities of surface and whole-tissue extracts of marine organisms have not been studied detail (Nylund et al. 2007). In this study, bacterial growth (spectrophotometer method) and biofilm inhibitory activity (microtitre plate assay) of the surface extract were higher than the total extract. The good performance of surface extract in antibiofilm assay raises the further question on the source of the secondary metabolites. Many studies indicated that the epibiotic microbial communities associated with marine organisms are providing the defence to the host against the colonizers and competitors (see review: Satheesh et al. 2016). Further, fresh algal samples were used for surface and total extraction in this study. Hence, the possibility for the presence of metabolites from epibiotic microbial sources cannot be ruled out in both surface and total extracts.

The concentration of metabolites in tissue extracts (total extract) may also be higher than the surface extracts (Sudatti et al. 2006). This difference may be due to the chemical defence mechanism in macroalgae that usually store the compounds in tissues and transported to the surfaces (see review: da Gama et al. 2014). However, results from the GC-MS analysis in this study confirmed an important aspect that the surface extract possess higher number of metabolites than the total extract. The good performance of surface extract in anti-settlement assay might be due to the presence of a large num- 
ber of compounds, which need further studies. Some of the compounds identified from the surface extract such as azetidine-2-one, piperidine, propanamide and imidazole derivatives have potent pharmacological activities (Olgen et al. 2008; Noolvi et al. 2014; Sharma et al. 2016; Zhang et al. 2017). Imidazole and piperidines exhibited antifouling activities in previous studies (Majik et al. 2014; Huang et al. 2014). Among the compounds present in both surface extracts total extracts, phthalic acid derivate is reported to possess antifouling activities (Ganti et al. 2006).

In conclusion, the bioactive compounds present in the extract of $D$. dichotoma could be used as natural product antifoulants. The presence of many compounds in the surface extract confirmed the role of surface-associated molecules in antifouling chemical defence of marine macroalgae. While the source of surface-associated molecules needs further investigation, these metabolites could be used as a potential compounds for antifouling assays against invertebrate larvae and other organisms. In addition, the study emphasizes the role of surface extraction method in natural product antifouling screening assays.

\section{Acknowledgement}

We thank King Abdulaziz City for Science and Technology (KACST) for providing financial assistance for this study through graduate students program to the first author (grant number: PS- 37-1109).

\section{References}

Águila-Ramírez RN, Arenas-González A, Hernández-Guerrero CJ, González-Acosta B, Borges-Souza JM, Véron B, Pope J, Hellio C. 2017. Antimicrobial and antifouling activities achieved by extracts of seaweeds from Gulf of California, Mexico. Hidrobiológica 22: 8-15.

Antonysamy JMA, Velayutham K, Mani N, Thangaiah S, Irullappan R. 2015. Antibacterial, cytotoxic and larvicidal potential of Dictyota bartayresiana Lamour. Journal of Coastal Life Medicine 3: 352-355.

Armstrong E, Boyd KG, Burgess JG. 2000. Prevention of marine biofouling using natural compounds from marine organisms. Biotechnology Annual Review 6: 221-241.

Ba-Akdah MA, Satheesh S, Al-Sofyani A.A. 2016. Habitat preference and seasonal variability of epifaunal assemblages associated with macroalgal beds on the Central Red Sea coast, Saudi Arabia. Journal of the Marine Biological Association of the United Kingdom 96: 1457-1467.

Balqadi AA, Salama AJ, Satheesh S. 2017. Microfoul- ing development on artificial substrates deployed in the central Red Sea. Oceanologia. https://doi. org/10.1016/j.oceano.2017.10.006

Baumgarten T, Sperling S, Seifert J, von Bergen M, Steiniger F, Wick LY, Heipieper HJ. 2012. Membrane vesicle formation as a multiple-stress response mechanism enhances Pseudomonas putida DOT-T1E cell surface hydrophobicity and biofilm formation. Applied and Environmental Microbiology 78: 6217-6224.

Bellas J. 2006. Comparative toxicity of alternative antifouling biocides on embryos and larvae of marine invertebrates. Science of the Total Environment 367: 573-585.

Burns E, Ifrach I, Carmeli S, Pawlik JR, Ilan M. 2003. Comparison of anti-predatory defenses of Red Sea and Caribbean sponges. I. Chemical defense. Marine Ecology Progress Series 252: 105-114.

Carvalho AP, Batista D, Dobretsov S, Coutinho R. 2017. Extracts of seaweeds as potential inhibitors of quorum sensing and bacterial growth. Journal of Applied Phycology 29: 789-797.

Choi NY, Kim BR, Bae YM, Lee SY. 2013. Biofilm formation, attachment, and cell hydrophobicity of food borne pathogens under varied environmental conditions. Journal of the Korean Society for Applied Biological Chemistry 56: 207-220.

Clare AS. 1998. Towards nontoxic antifouling. Journal of Marine Biotechnology 6: 3-6.

Coffey BM, Anderson GG. 2014. Biofilm formation in the 96-well microtiter plate. In: Pseudomonas Methods and Protocols. New York: Humana Press. p 631641

da Gama BA, Plouguerne E, Pereira RC. 2014. The antifouling defence mechanisms of marine macroalgae. Advances in Botanical Research 71: 413-440.

Dahms HU, Dobretsov S. 2017. Antifouling compounds from marine macroalgae. Marine Drugs 15: 265. doi:10.3390/md15090265.

de Nys R, Steinberg PD, Willemsen P, Dworjanyn SA, Gabelish CL, King RJ. 1995. Broad spectrum effects of secondary metabolites from the red alga Delisea pulchra in antifouling assays. Biofouling 8: 259-271.

Dubber D, Harder T. 2008. Extracts of Ceramium rubrum, Mastocarpus stellatus and Laminaria digitata inhibit growth of marine and fish pathogenic bacteria at ecologically realistic concentrations. Aquaculture 274: 196-200

El-Din SMM, El-Ahwany AM. 2016. Bioactivity and phytochemical constituents of marine red seaweeds (Jania rubens, Corallina mediterranea and Pterocladia capillacea). Journal of Taibah University for Science 10: 471-484.

Evans SM, Leksono T, McKinnell PD. 1995. Tributyltin 
pollution: a diminishing problem following legislation limiting the use of TBT-based anti-fouling paints. Marine Pollution Bulletin 30: 14-21.

Fingerman SW. 1988. Environmental pollution by heavy metals from antifouling compounds. In: Thompson MF, Sarojini R, Nagabhushanam R, Editors. Marine Biodeterioration: Advanced techniques applicable to the Indian Ocean. New Delhi: Oxford \& IBH. p. 781789.

Fusetani N. 2004. Biofouling and antifouling. Natural Product Reports 21: 94-104.

Ganti VS, Kim KH, Bhattarai HD, Shin HW. 2006. Isolation and characterisation of some antifouling agents from the brown alga Sargassum confusum. Journal of Asian Natural Products Research 8: 309-315.

Giaouris E, Chapot-Chartier MP, Briandet R. 2009. Surface physicochemical analysis of natural Lactococcus lactis strains reveals the existence of hydrophobic and low charged strains with altered adhesive properties. International Journal of Food Microbiology 131: 2-9.

Greer SP, Iken KB, McClintock JB, Amsler CD. 2003. Individual and coupled effects of echinoderm extracts and surface hydrophobicity on spore settlement and germination in the brown alga Hincksia irregularis. Biofouling 19: 315-326.

Hadfield MG, Paul VJ. 2001. Natural chemical cues for settlement and metamorphosis of marine invertebrate larvae. In: McClintock JB, Baker BJ, Editors. Marine chemical ecology. Boca Raton :CRC. p. 431461.

Hellio C, De La Broise D, Dufosse L, Le Gal Y, Bourgougnon N. 2001. Inhibition of marine bacteria by extracts of macroalgae: potential use for environmentally friendly antifouling paints. Marine Environmental Research 52: 231-247.

Hellio C, Maréchal JP, Da Gam, BAP, Pereira R C, Clare A. 2009. Marine natural products with antifouling activities. In: Hellio C, Yebra DM, Editors. Advances in marine antifouling coatings and technologies. Cambridge: Woodhead Publishing. p. 572-609.

Hoch M. 2001. Organotin compounds in the environment-an overview. Applied Geochemistry 16: 719 743.

Huang XZ, Xu Y, Zhang YF, Zhang Y, Wong YH, Han Z, Yin Y, Qian PY. 2014. Nontoxic piperamides and their synthetic analogues as novel antifouling reagents. Biofouling 30: 473-481.

Huang Y, Callahan S, Hadfield MG. 2012. Recruitment in the sea: bacterial genes required for inducing larval settlement in a polychaete worm. Science Reporter 2:228. http://dx.doi.org/10.1038/srep00228

Kochkodan V, Tsarenko S, Potapchenko N, Kosinova V, Goncharuk V. 2008. Adhesion of microorganisms to polymer membranes: a photobactericidal effect of surface treatment with TiO2. Desalination 220: 380385

Krasowska A, Sigler K. 2014. How microorganisms use hydrophobicity and what does this mean for human needs? Frontiers in Cellular and Infection Microbiology $4: 112$.

Lam C, Stang A, Harder T. 2008. Planktonic bacteria and fungi are selectively eliminated by exposure to marine macroalgae in close proximity. FEMS Microbiology Ecology 63:283-291.

Lopanik NB. 2014. Chemical defensive symbioses in the marine environment. Functional Ecology 28: 328340

Lu K, Lin W, Liu J. 2008. The characteristics of nutrient removal and inhibitory effect of Ulva clathrata on Vibrio anguillarum 65. Journal of Applied Phycology, 20: 1061 .

Ma C, Zhang W, Zhang G, Qian PY. 2017. Environmentally friendly antifouling coatings based on biodegradable polymer and natural antifoulant. ACS Sustainable Chemistry \& Engineering 5: 6304-6309.

Majik MS, Tilvi S, Mascarenhas S, Kumar V, Chatterjee A, Banerjee M. 2014. Construction and screening of 2-aryl benzimidazole library identifies a new antifouling and antifungal agent. RSC Advances 4: 28259-28264.

Noolvi M, Agrawal S, Patel H, Badiger A, Gaba M, Zambre A. 2014. Synthesis, antimicrobial and cytotoxic activity of novel azetidine-2-one derivatives of 1H-benzimidazole. Arabian Journal of Chemistry 7: 219-226.

Nylund GM, Pavia H. 2005. Chemical versus mechanical inhibition of fouling in the red alga Dilsea carnosa. Marine Ecology Progress Series 299: 111-121.

Nylund GM, Gribben PE, de Nys R, Steinberg PD, Pavia $H$. 2007. Surface chemistry versus whole-cell extracts: antifouling tests with seaweed metabolites. Marine Ecology Progress Series 329: 73-84.

Ölgen S, Altanlar N, Karatayl E, Bozday M. 2008. Antimicrobial and antiviral screening of novel indole carboxamide and propanamide derivatives. Zeitschrift für Naturforschung C 63: 189-195.

Othmani A, Bunet R, Bonnefont JL, Briand JF, Culioli G. 2016. Settlement inhibition of marine biofilm bacteria and barnacle larvae by compounds isolated from the Mediterranean brown alga Taonia atomaria. Journal of Applied Phycology 28: 1975-1986.

Pan H, Zhang Y, He GX, Katagori N, Chen H. 2014. A comparison of conventional methods for the quantification of bacterial cells after exposure to metal oxide nanoparticles. BMC Microbiology 14: 222.

Paul VJ, Cruz-Rivera E, Thacker RW. 2001. Chemical mediation of macroalgal-herbivore interactions: eco- 
logical and evolutionary perspectives. In: McClintock JB, Baker BJ, Editors. Marine chemical ecology. Boca Raton, FL: CRC Press. p. 227-265

Paul NA, de Nys R, Steinberg PD. 2006. Chemical defence against bacteria in the red alga Asparagopsis armata: linking structure with function. Marine Ecology Progress Series 306:87-101.

Pérez MJ, Falqué E, Domínguez H. 2016. Antimicrobial action of compounds from marine seaweed. Marine Drugs 14: 52

Plouguerne E, Hellio C, Deslandes E, Véron B, Stiger-Pouvreau V. 2008. Anti-microfouling activities in extracts of two invasive algae: Grateloupia turuturu and Sargassum muticum. Botanica Marina 51: 202208

Qian PY, Xu Y, Fusetani N. 2009. Natural products as antifouling compounds: recent progress and future perspectives. Biofouling 26: 223-234.

Rohde S, Nietzer S, Schupp PJ. 2015. Prevalence and mechanisms of dynamic chemical defenses in tropical sponges. PloS one 10: e0132236.

Rosenberg M, Gutnick D, Rosenberg E. 1980. Adherence of bacteria to hydrocarbons: a simple method for measuring cell-surface hydrophobicity. FEMS Microbiology Letters 9: 29-33.

Sacristán-Soriano O, Angulo-Preckler C, Vázquez J, Avila C. 2017. Potential chemical defenses of Antarctic benthic organisms against marine bacteria. Polar Research 36: 1390385. https://doi.org/10.1080/1751836 9.2017.1390385

Saha M, Wahl M. 2013. Seasonal variation in the antifouling defence of the temperate brown alga Fucus vesiculosus. Biofouling 29: 661-668.

Salama AJ, Satheesh S, Balqadi AA. 2017. Antifouling activities of methanolic extracts of three macroalgal species from the Red Sea. Journal of Applied Phycology. https://doi.org/10.1007/s10811-017-1345-6.

Salta M, Wharton JA, Dennington SP, Stoodley P, Stokes KR. 2013. Anti-biofilm performance of three natural products against initial bacterial attachment. International Journal of Molecular Sciences 14: 21757 21780.

Satheesh S, Wesley SG. 2008. Seasonal variability of fouling community recruitment in Kudankulam coastal waters, East coast India, Estuarine Coastal and Shelf Science 79: 518- 524. doi:10.1016/j.ecss.2008.05.008.

Satheesh S, Soniamby AR, Shankar CS, Punitha SMJ. 2012. Antifouling activities of marine bacteria associated with sponge (Sigmadocia sp.). Journal of Ocean University of China 11: 354-360.

Satheesh S, Ba-akdah MA, Al-Sofyani AA. 2016. Natural antifouling compound production by microbes associated with marine macroorganisms-A review.
Electronic Journal of Biotechnology 21: 26-35.

Sayem SA, Manzo E, Ciavatta L, Tramice A, Cordone A, Zanfardino A, De Felice M, Varcamonti M. 2011. Anti-biofilm activity of an exopolysaccharide from a sponge-associated strain of Bacillus licheniformis. Microbial Cell Factories 10:74.

Schultz MP. 2004. Frictional resistance of antifouling coating systems. Journal of Fluids Engineering 126: 1039-1047.

Sharma A, Kumar V, Kharb R, Kumar S, Chander Sharma P, Pal Pathak D. 2016. Imidazole derivatives as potential therapeutic agents. Current pharmaceutical design 22: 3265-3301

Sipkema D, Franssen MCR, Osinga R, Tramper T, Wijffels RH. 2005. Marine sponges as pharmacy. Marine Biotechnology 7: 142-162.

Stoodley P, Sauer K, Davies DG, Costerton JW. 2002. Biofilms as complex differentiated communities. Annual Reviews in Microbiology 56: 187-209.

Sudatti DB, Rodrigues SV, Pereira RC. 2006. Quantitative GC-ECD analysis of halogenated metabolites: determination of elatol on surface and within-thallus of Laurencia obtusa. Journal of Chemical Ecology 32: 835-843.

Sudatti DB, Rodrigues SV, Coutinho R, Da Gama BA, Salgado LT, Amado Filho GM, Pereira RC. 2008. Transport and defensive role of elatol at the surface of the red seaweed Laurencia obtusa (Ceramiales, Rhodophyta). Journal of Phycology 44: 584-591.

Thomas KV, Brooks S. 2010. The environmental fate and effects of antifouling paint biocides. Biofouling 26: 73-88.

Viano Y, Bonhomme D, Camps M, Briand JF, Ortalo-Magné A, Blache Y, Piovetti L, Culioli G. 2009. Diterpenoids from the Mediterranean brown alga Dictyota sp. evaluated as antifouling substances against a marine bacterial biofilm. Journal of Natural Products 72: 1299-1304.

Viju N, Satheesh S, Punitha SMJ. 2016. Antibiofilm and antifouling activities of extracellular polymeric substances isolated from the bacteria associated with marine gastropod Turbo sp. Oceanological and Hydrobiological Studies 45: 11-19.

Wang KL, Wu ZH, Wang Y, Wang CY, Xu Y. 2017. Mini-Review: Antifouling natural products from marine microorganisms and their synthetic analogs. Marine drugs 15: 266.

Zhang X, Lei P, Sun T, Jin X, Yang X, Ling Y. 2017. Design, synthesis, and fungicidal activity of novel thiosemicarbazide derivatives containing piperidine fragments. Molecules 22: 2085. 